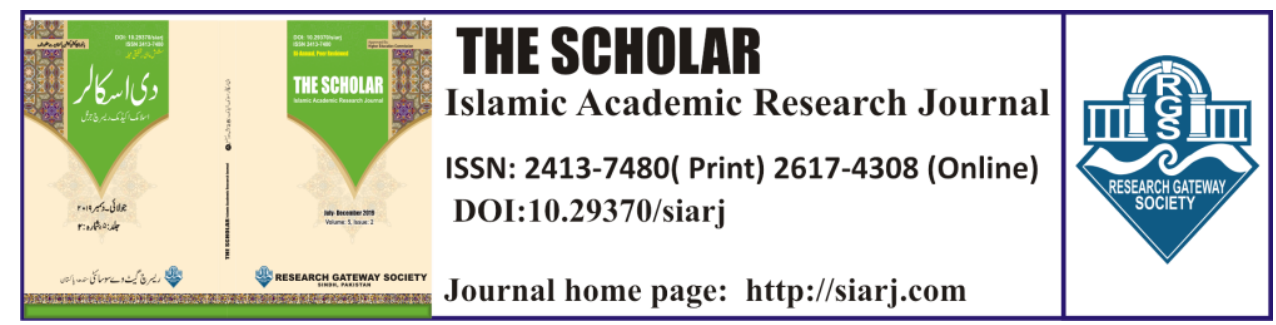

\title{
MEASURING THE IMPACT OF ISLAMIC MICROFINANCE PRODUCT,QARZ-E- HASNA, ON POVERTY ALLEVIATION IN HYDERABAD DISTRICT
}

\section{Abdul Ghafoor Ansari}

Mehran University Institute of Science, Technology \& Development, Jamshoro Email: agansari50@gmail.com ORCIID IID:

https://orcid.org/0000-0002-9987-5290

\section{Muhammad Saleh Ansari}

Mehran University Institute of Science, Technology \& Development, Jamshoro Email: rmsansari@gmail.com ORCIID IID:

https://orcid.org/0000-0003-4664-9633

\section{Dr. Basheer Ahmed Dars}

Faculty Member. Mehran University, SZAB Campus Khiarpur Mir's, Sindh, Pakistan.

Email: bashirdars@muetkhp.edu.pk

\section{ORCIID IID:}

https://orcid.org/0000-0003-4664-9633

To cite this article:

Ansari, Abdul Ghafoor, Muhammad Saleh Ansari, and Basheer Ahmed Dars.

"MEASURING THE IMPACT OF ISLAMIC MICROFINANCE

PRODUCT,QARZ-E-HASNA, ON POVERTY ALLEVIATION IN HYDERABAD

DISTRICT." The Scholar-Islamic Academic Research Journal 5, No. 2 (December 16, 2019): 139-163.

To link to this article: https://doi.org/10.29370/siarj/issue9ar14

\begin{tabular}{|c|c|}
\hline Journal & $\begin{array}{l}\text { The Scholar Islamic Academic Research Journal } \\
\text { Vol. 5, No. } 2 \text { || July -December } 2019 \text { ||P. 139-163 }\end{array}$ \\
\hline Publisher & Research Gateway Society \\
\hline DOI: & 10.29370/siari/issue9ar14 \\
\hline URL: & https://doi.org/10.29370/siarj/issue9ar14 \\
\hline License: & Copyright c 2017 NC-SA 4.0 \\
\hline Journal homepage & www.siari.com \\
\hline Published online: & 2019-16-12 \\
\hline
\end{tabular}
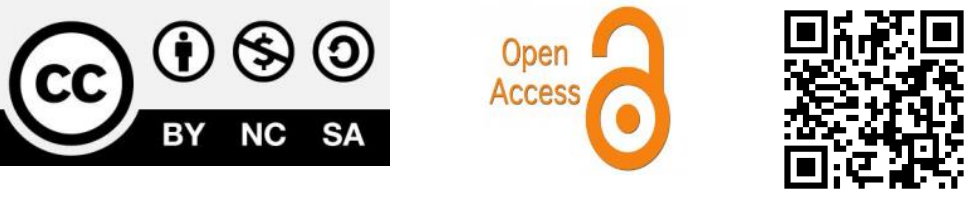
THE SCHOLAR (July - December 2019)

\title{
MEASURING THE IMPACT OF ISLAMIC MICROFINANCE PRODUCT, QARZ-E-HASNA, ON POVERTY ALLEVIATION IN HYDERABAD DISTRICT
}

Abdul Ghafoor Ansari, Muhammad Saleh Ansari, Basheer Ahmed Dars

\begin{abstract}
:
The objective of this study is to analyze the impact of Islamic microfinance product "Qarz-e-Hasna"provide byan Islamic philanthropic organization Akhuwat on the poverty alleviation of its beneficiaries. The study uses primary data collected through personally structured questionnaire on the randomly selected sample of 120 out of the population of 1196beneficiaries of Akhuwat Hyderabad branch. The study found that majority of the beneficiaries were Muslim women within the age groups of 21 to 40 years have obtained the loan of Rs.20,000 each and utilized it for the purpose to expanding their small businesses. The results indicates that Qarz-e-Hasna has improved the living standard of the beneficiaries on accounts of income, expenditure, saving, educational level, households and business assets. Majority of the beneficiaries are satisfied with the terms of loan and the services of Akhuwat.
\end{abstract}

KEYWORDS: Islamic Microfinance, Akhuwat, Qarz-e-Hasna, Poverty alleviation.

\section{INTRODUCTION:}

Muslims claim that "Islam" is complete code of life that provides guide lines in all aspects of life, whether it is related to may be Aqaaid (tenets), Ibadat (ritual worship), Muashrat (Social Regulations), Ikhlaqiat 
THE SCHOLAR (July - December 2019)

(Behaviour) and Muamlat (means of earnings). It identifies the lawful and permissible products and practices as well as unlawful and prohibited products and practices for the Muslims that are called HALAL \& HARAM.

Figure 0-1Framework of Islam ${ }^{1}$

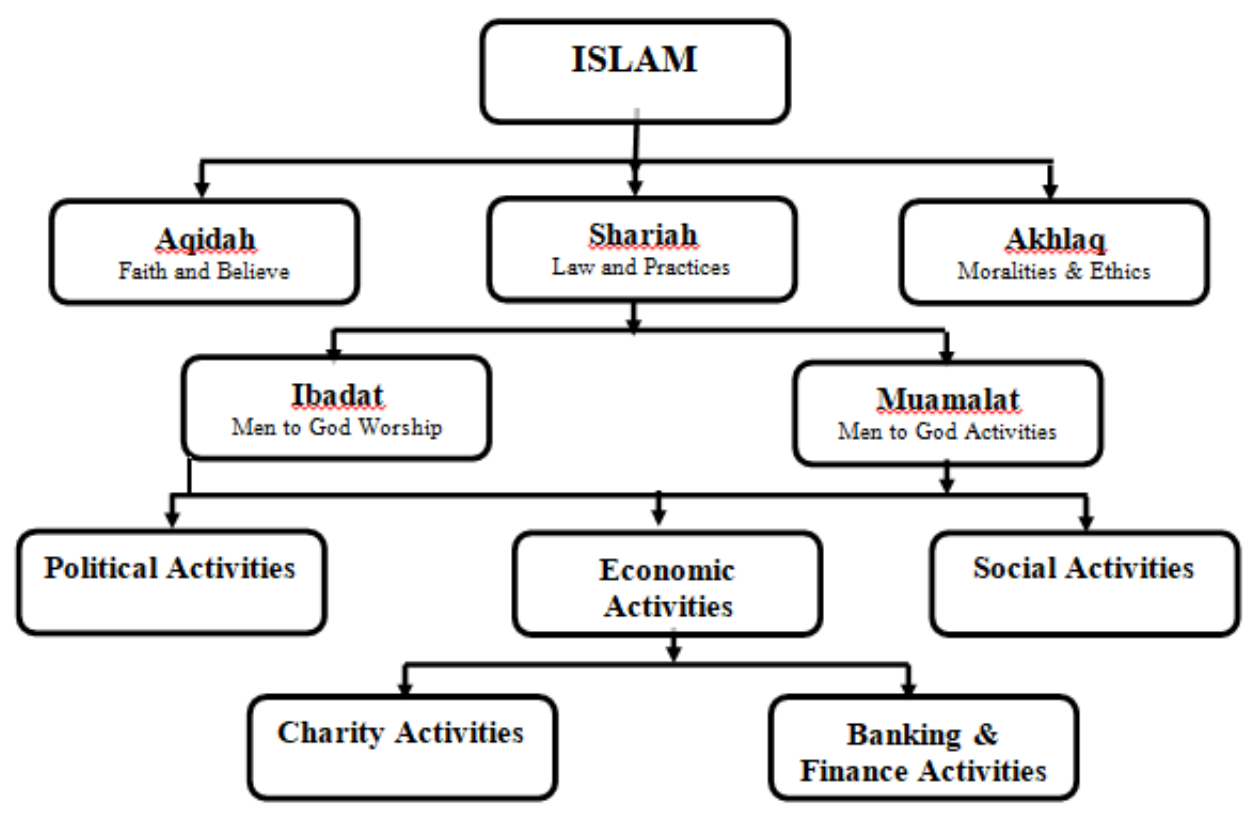

The concept / philosophy of Islamic Finance is based on the ontology of permissible and prohibited (Halal and Haram) believes. In economic dealings, Islam strictly put a prohibition on the interest based transactions. In this regards, Holy Quran verse No.2:275 clearly says:

\footnotetext{
1“IslamicMarkets.Com.” Accessed December 12, 2019. https://islamicmarkets.com.
} 


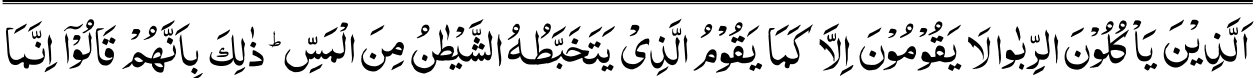

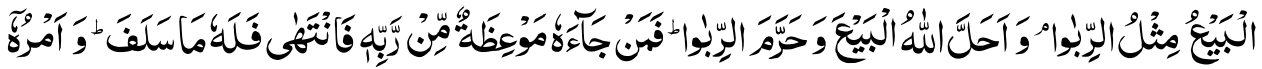

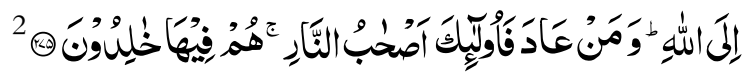

"Those who consume interest cannot stand [on the Day of Resurrection] except as one stands who is being beaten by Satan into insanity. That is because they say, "Trade is [just] like interest." But Allah has permitted trade and has forbidden interest. So whoever has received an admonition from his Lord and desists may have what is past, and his affair rests with Allah. But whoever returns to [dealing in interest or usury] - those are the companions of the Fire; they will abide eternally therein."

Riba (Interest) has been declared Haram while Baiy (Trade) declared Halal mode of the earnings.

Therefore, in accordance to the Shari'ahh various contracts and products have been introduced by the Islamic Banking and Financial Institutions as depicts below:

\section{Figure 0-2Framework of Islamic Banking and Finance}

${ }^{2}$ Al-Quran: (2). 275 
THE SCHOLAR (July - December 2019)

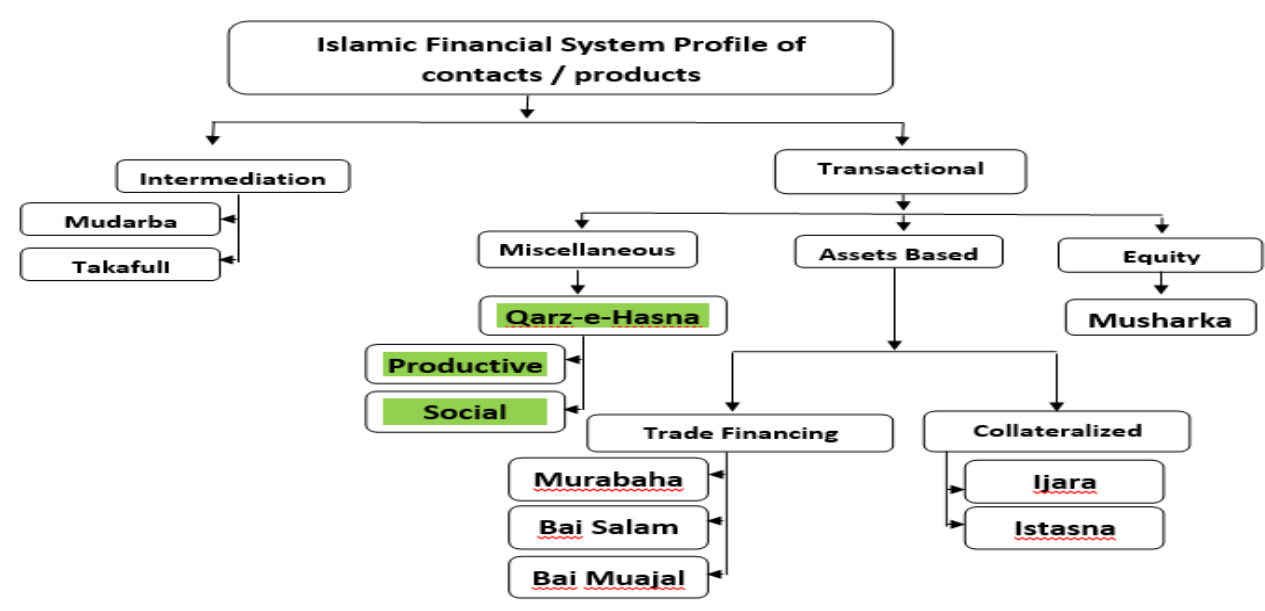

\section{BACKGROUND:}

The informal Islamic Finance practices were present in the Muslim societies since the inception of Islam. With the formation of formal Islamic banking institutions during the 1970s the modern practices of Islamic banking and finance are flourishing tremendously and presently quantum of Islamic Finance in the world is in trillions US dollars.

To mitigate the economic inequalities persist in the society, the inherent social justice potential of Islam has provided system of Zakat, Sadqat and Waqaf for distribution of the acquired wealth among the poor.

Microfinance is an important and efficient tool in the global battle against poverty. Kofi Annan former Secretary General of United Nation expressed Microfinance as:

"Let us be clear; Microfinance is not charity. It is a way to extend the same rights and resources to low income households that are available to everyone else. It is recognition that poor people are the solution, not the 
Measuring the Impact of Islamic Microfinance Product, Qarz-E-Hasna, on Poverty Alleviation in Hyderabad District

"problem. It is way to build their ideas, energy and vision. It is a way to grow productive enterprise and to allow communities to prosper. ",

While conventional microfinance products and services have been practicing in the world, they do not fulfill the needs of Muslim communities, because of interest. Therefore Islamic microfinance has a potential to expand financial access to the cliental which currently rejects microfinance products that do not comply with Islamic Law. The Islamic microfinance represents the confluence of two rapidly growing industries i.e. microfinance (MF) and Islamic finance (IF).

The microfinance is a tool to combat poverty. This tool is selected by the government of Pakistan as poverty reduction strategy by issuing microfinance ordinance in the year 2001. Beside State bank of Pakistan stepped up in 2007 to introduce Islamic microfinance guide line to promote Islamic microfinance institutions (IMFIs) in the country. There are various conventional and Islamic microfinance institutions (MFIs) in Pakistan extending facilities to the poor for improving their living standards.

The conventional microfinance institution charge high rates of interest, demand collaterals and are operated on the national \& international aids and grants. Therefore their products are interest based and costly. However, there are Islamic microfinance institution functioning in Pakistan and provide effective products to the poor. AKHUWAT is one of those Islamic microfinance institutions which "Qarz-e-Hasna”, an Islamic microfinance product without charging any cost on their financial schemes

\footnotetext{
${ }^{3}$ Video message at the launch of the International year of Microcredit 2005, 18 November 2004 http://www.un.otg/News/Press/docs/2004/sgsm9601.doc.htm.
} 
Measuring the Impact of Islamic Microfinance Product, Qarz-E-Hasna, on Poverty Alleviation in Hyderabad District

as well as do not demand any collateral from the clients. Akhuwat receives its funds from local donations given by the philanthropist organizations and individuals.

To know whether Qarz-e-Hasna an Islamic microfinance product of Akhuwat is plying any role in combating the poverty in the country? Therefore study has been conducted.

AKUWAT was established in 2001 for the purpose to provide interest free loans to the poor for productive and social purposes. With the passage of time it becomes a successful organization. It is registered under Societies Act 1860 and is member of Pakistan Center for Philanthropy (PCP) and Pakistan Microfinance Network (PMN), its head office is at Lahore, Pakistan and Regional, Area and Branch Offices are all over the country. ${ }^{4}$ It offers free benevolent loan called Qarz-e-Hasna for businesses and social purposes. It also provides lending services to various government organizations i.e. Government of Pakistan, Punjab, KPK, GB and FATA Administration as well as Punjab Small Industries Corporation Limited (PSIC) and charges operational costs@ @ on the interest free loans disbursed on behalf of the above organization.

Its source of funding are the donations from the members of board of directors and local philanthropist it does not accept donations and grants from international donors and agencies and no loan from interest based organizations of Pakistan like Pakistan Poverty Alleviation Finds (PPAF) and Asian Development Bank (ADB).

${ }^{4}$ Kiran Siddiqi (2008). Potential of Islamic Microfinance in Pakistan. Dissertation submitted in partial fulfilment of the requirements for the degree of M.A. in MA Islamic Banking, Finance \& Management (In association with Loughborough University). 
Measuring the Impact of Islamic Microfinance Product, Qarz-E-Hasna, on Poverty Alleviation in Hyderabad District

\section{LITERATURE REVIEW:}

The Ubaidullah and Khan established that high rate of poverty is in Muslim countries, over half billion individuals live on under \$2 per day in Indonesia, India, Bangladesh, Egypt, Nigeria \& Pakistan and Micro Credit is an effective tool to combat poverty in these countries ${ }^{5}$. Economics Survey of Pakistan reported $24.3 \%$ of Pakistan population lives under poverty line ${ }^{6}$

The study said that in previous decades the microfinance has shown considerable growth and is recognized as most effective tool for reduction of the poverty ${ }^{7}$, also Mallika and Udara concludes that microfinance has directly caused to increase the income of beneficiaries and there is positive impact on new income sources as well ${ }^{8}$. FredN'Mbololo analyzed in his thesis that there is significant impact of microfinance facilities on the improvement of the living standard of the beneficiaries in economic and social terms ${ }^{9}$. Iqbal and Musthaque said that poor people can fulfill their basic needs, improve their living standard and get self-employment by using the financial services of microfinance institutions hence can reduce

\footnotetext{
5Ubaidullah, Muhammad.(2008). "Islam, Poverty and Microfinance best practices" ${ }^{6 ، \mid}$ Ministry of Finance | Government of Pakistan |.” Accessed December 12, 2019. http://www.finance.gov.pk/.

${ }^{7}$ Miled and Rejeb. (2018). Can Microfinance Help to Reduce Poverty? A Review of Evidence for Developing Countries. Journal of the Knowledge Economy, Volume 9 , Issue 2: PP 613-635.

${ }^{8}$ Mallika and Udara. (2019). Microfinance as an Instrument for Economic empowerment of the Poor People in Srilanka. Proceedings of International Multi Conference of Engineers and Computer Sciencts at Hongkong

9 FredM'mbololo. (2013). Thesis “Microfinance Awareness and Impact in Kenya". Hassan and Saleem. (2017). An Islamic Microfinance Business Model in Bangladesh. Humanomics Volume 33 No.1.
} 
Measuring the Impact of Islamic Microfinance Product, Qarz-E-Hasna, on Poverty Alleviation in Hyderabad District

their poverty level ${ }^{10}$. Mahesh K. noticed that there is a significant impact of microfinance activities on improvement of the living standards of a family not only in economic terms but also in social terms ${ }^{11}$. Charles and James concludes that programs offered by the microfinance institutions are of the potential to raise the income level and decrease the vulnerability ultimately combat the poverty, promote economic capacity and bring sustainable development in the society ${ }^{12}$.

Gebru and Paul identified that one main hindrance poor is facing is lack of access to formal credit to enable them to improve their level of standard so that to move out of poverty ${ }^{13}$.

CGAP reports that interest rates are the major source of income and need to be high so that microfinance institutions can cover their operational costs and continue to provide microfinance services to the poor. ${ }^{14}$ Mushimiyimana identified that non availability of collateral and increased interest rates are the hindrance to avail the credit from Microfinance Institutions ${ }^{15}$. Bourhin and Tkiouat identified that charging high interest

\footnotetext{
${ }^{10}$ Iqbal and Mushtaque. (2015). Impact of Microfinance on Poverty Alleviation: The Study of District Bahawal Nagar, Punjab, Pakistan, Management and Administration Services Review.

${ }^{11}$ B N, Prathap \& Mahesh, Dr \& Karthik, K. (2018). Impact of Micro Finance on Poverty Alleviation. 5. 278-286.

${ }^{12}$ Charles. A and James. (2011). Impact of Microfinance on Poverty Alleviation in Nigeria : An Empirical Investigation, European Journal of Humanities and Social Sciences. Volume 2 No.1.

${ }^{13}$ Bisrat Gebru \& Issac Paul, Journal of Sustainable Development in Africa (Volume 13, No.6, 2011), ISSN: 1520-5509, Clarion University of Pennsylvania, Clarion, Pennsylvania ${ }^{14}$ CGAP. (2013). Economic Microfinance in Pakistan: The experience so far. An article written by Khadija Ali, published in CGAP Bulletin.

${ }^{15}$ Mushimiyimana A (2008). Analysis of access to MFIs loans by women entrepreneurs and impact on their business. University of Nairobi.
} 
Measuring the Impact of Islamic Microfinance Product, Qarz-E-Hasna, on Poverty Alleviation in Hyderabad District

rates limit the role of micro credit as poverty alleviation tool. ${ }^{16}$ Also Zahoor Khan and Asmatullah clarified that conventional microfinance is costly and not affordable for poor and needy, also people are aware about the Islamic Shari'ah which prohibits interest under any circumstances. ${ }^{17}$ A well known news paper Express Tribune reports that in 1970 worth of Islamic Financial Assets world wise was US\$.0.5 millions that has been increased @ 14\% per annum to over US\$.1.000 Trillion by $2009 .{ }^{18}$ Smith and Haddad are of the opinion that "Engaging in Islamic Finance be understood as an ethical duty, to emphasize human accountability and fulfillment of this worthy endeavors in the world to come"19. However, Hassan \& Saleem identified that Current Operation of most of the Islamic Microfinance Institutions is not in alignment of Sharia, However, efforts are being taken to follow $\mathrm{it}^{20}$. Further it is argued by Usman that poor Muslims significantly reject traditional micro loans. ${ }^{21}$

Salman \& Nawaz reveals that the future of Islamic Banking in terms of their performance measured is brighter than conventional banking. ${ }^{22}$ According to Amer, the rich inherent social justice potential of Islam has

\footnotetext{
${ }^{16}$ Bourhim and Tkiouat. (2018). Rethinking Microfinance in Dual Financial System: An Agent Based Simulation. Scientific Annals of Economics and Business 65 (1) PP 13-29

${ }^{17}$ Zahoor Khan, Asmatullah.(2010). "Commercial v/s Cooperative Microfinance Program: an investigation of efficiency, performance and sustainability" the dialog volume-v number 2.

${ }^{18}$ Express Tribune (Pakistan) 2 January 2015 “Across the world: Islamic Banking Assets Cross 2T" FredM'mbololo. (2013). Thesis "Microfinance Awareness and Impact in Kenya".

${ }^{19}$ Smith \& Hadad.(2002). "The Islamic understanding of death and Resurrection" Oxford: Oxford University Press.

${ }^{20}$ Hassan and Saleem. (2017). An Islamic Microfinance Business Model in Bangladesh. Humanomics Volume 33 No.1.

${ }^{21}$ Ahmad, Usman. (2011). Efficiency Analysis of Microfinance Institutions in Pakistan.

${ }^{22}$ Salman and Nawaz. (2018). Islamic Financial System and Conventional Banking: A Comparison, Arab Islamic and Business Journal 13, PP 155-167
} 
Measuring the Impact of Islamic Microfinance Product, Qarz-E-Hasna, on Poverty Alleviation in Hyderabad District

been underutilized for poverty alleviation in the world. ${ }^{23}$ Brant, Ekmeleddin Ihsanovlu, Secretary General of OIC views Islamic Finance as a complementary service instead of alternative to conventional banking. ${ }^{24}$ Lewis \& Algaoud and Kuran says actually wealth is not inherently immoral; the Quran allows for the acquisition of wealth and acknowledge that wealth disparities will always exists. ${ }^{25}$ Khan and Philips further elaborated that "The core belief in Islamic Finance is that: money is not earning assets itself, risk must be present in commercial or productive activity and transaction should be directly or indirectly linked to tangible economic activity and not financial speculations"26. El-Gamal, Khan therefore identified a split between two types of IBFIs; those focusing on technical Shari'ah compliance in their contract forms and those devoted to the social justice mission of Islam. ${ }^{27}$ Beside, Kroessin, justified that Shari'ah Complaint financing can promote financial inclusion of population who are self-excluded from conventional financing. ${ }^{28}$ Thompson Reuters is of the opinion that concept of family empowerment is promoted by Islam wherein men and women have to play their

\footnotetext{
${ }^{23}$ Amer, Hady. (2008). The brooking project on US relations with Islamic World-Dooha Discussion Papers: Human Development in Muslim world Washington DC: Saban Center for Middle East policy at Brookings.

${ }^{24}$ Kuran, Timur. (2010). The long divergence: How Islamic Law held back the middle east. Princton, NJ: Princton University Press.

25، World's Largest Interest Free Micro-Finance Organization." Accessed December 12, 2019. https://akhuwat.org.pk/.

${ }^{26}$ Khan, A.A. and Phillips, I. (2010), The Influence of Faith on Islamic Microfinance Programmes, Islamic Relief Worldwide, Birmingham.

${ }^{27}$ El Gamal, Mahmoud. (2006). Islamic Finance: Law, Economics and practice. Combridge: Combridge Press and Khan, M.S (1986) "Islamic Interest Free Banking: A theoretical analysis" International Monetary Fund: Staff papers, PP 1-25

${ }^{28}$ Keroessin, Muhammad. (2012). "Islamic Micro Finance at Cross Roads" Islamic Finance review volume 2: PP 44-46.
} 
The Scholar Islamic Academic Research Journal

Vol. 5, No. 2 || July-December 2019 || P. 139-163

https://doi.org/10.29370/siarj/issue8ar14

respective roles for economic and social welding of all family members. ${ }^{29}$ Iqbal concluded that Islamic Banking Industry may review to meet the demand of more sophisticated products and services. It should be innovative rather than replicate the conventional banking products to satisfy the customer needs. ${ }^{30}$

Pakistan is considered a promising market for Islamic Microfinance because $98 \%$ of its population is Muslim therefore in 2007 State Bank of Pakistan issued guidelines for establishment and promotion of Islamic Microfinance Institutions in the country. ${ }^{31}$ Tahir and Mertin identified that merit of Islamic Microfinance should be judged based on the rely on the interest free loans, dedicated charitable funds, loaning for enterprises, small loans for exceeding one year period and lower service charges. ${ }^{32}$ Hassan identified some approaches of Islamic Microfinance for combating the poverty as increasing in income, equitable distribution of wealth, equal opportunities for access to all social segments. ${ }^{33}$ Naveed analyzed that Islamic Microfinance in Pakistan is efficiently contributing to increase per capital income, living standard, awareness, ethical values, infrastructure and employment in the society. ${ }^{34}$ Kazim, Syeda and Haider studied that

\footnotetext{
${ }^{29}$ Gas-Aixendri, Montserrat \& Cavallotti, Rita. (2015). Family and Sustainable Development, Thomson Reuters Aranzadi, Cizur Menor 2015.

${ }^{30}$ SIDDIQUE, M., \& IQBAL, M. (2014). A Framework for Evaluating Islamic Banking from "Within". Islamic Studies, 53(1/2), 5-35. Retrieved December 12, 2019, from www.jstor.org/stable/44627365

31،'State Bank of Pakistan.” Accessed December 12, 2019. http://www.sbp.org.pk/.

${ }^{32}$ Tahir and Mertin. (2018). Affordability if Islamic Micro Finance. Journal of Technology Management and Business. Volume 5 No.3 PP 43-53.

${ }^{33}$ Hassan and Saleem. (2017). An Islamic Micro Finance Business Model in Bangladesh. Humanomics Volume 33 No.1.

${ }^{34}$ Naveed Aslam, Muhammad. (2014). Role of Islamic Microfinance in Poverty Alleviation in Pakistan: An Empirical Approach. International Journal of Academic
} 
The Scholar Islamic Academic Research Journal

Vol. 5, No. 2 || July-December 2019 || P. 139-163

https://doi.org/10.29370/siarj/issue8ar14

there are two models of Islamic Microfinance functioning in Pakistan one is being implemented by the Akhuwat successfully. ${ }^{35}$

Harper identified that contrary to the international level where recovery of group loans are more than individual loans, Akhuwat model of individual loan has higher recovery of dues ${ }^{35}$. Adnan, Zikri, Jaffar the Qarz-e-Hasna an instrument of Akhuwat shall help us to rethink the understanding approach for sources of funding and its sustainability. Khan, ${ }^{36}$ Naveed, Iqbal finds that Micro Credit facility of Akhuwat has positive relationship on the beneficiaries' social conditions, saving and purchasing powers, children education and employment opportunities thus it has minimized the poverty. ${ }^{37}$ Mehmood and Wahaj find that toward the end of loan cycle, those who go on to borrow again from Akuwat contribute more compare to those who do not. ${ }^{38}$ Rehman, Moazzam, Ansari they found that cooperation of the Akhuwat staff and the interest free loan was the major forces for the satisfaction of the clients of the Akhuwat. ${ }^{39}$

Research in Accounting, Finance and Management Sciences. 4. 10.6007/IJARAFMS/v4i4/1288.

${ }^{35}$ Islamic Microfinance Models And Their Viability In Pakistan By Syeda Shehrbano Kazim And Syed Eisar Haider.

${ }^{36}$ Adnan, Zikri and Jaafar. (2018). An Inquiry in to the sources of funding for Qarz-eHasna based MFIs : Case Study of Akhuwat. Scholarly Commons Wharton

Undergraduate Research, University of Pennsylvania.

${ }^{37}$ Khan, Naveed, Iqbal and Khan. (2018). Role of Micro Credit Activities of Akhuwat in Poverty Alleviation in District Nowshera. Journal of Business School. PP 47-59

${ }^{38}$ Mahmood and Wahaj. (2019). Charitable given are signaling voluntary contribution by Micro Credit Borrowers in Pakistan. Journal of Economic Behavior and Organization. 158 PP 394-415

${ }^{39}$ Rehman, Moazzam and Ansari. (2015). Roll of Micro Finance Institutions in Women Empowerment. A Case Study of Akhowat Pakistan. Research Journal of South Asian Studies. Volume 30. No.1 PP 109-125. 
The Scholar Islamic Academic Research Journal

Vol. 5, No. 2 || July-December 2019 || P. 139-163

https://doi.org/10.29370/siarj/issue8ar14

RESEARCH METHODOLOGY:

The Quantitative approach has been used for data collection and analysis.

The data required for the following objectives of this study have been collected from the primary sources through structured questionnaire.

i) Critically view the utilization of QARZ-E-HASNA availed by the poor for the productive and social purpose.

ii) Analyze the impact of QARZ-E-HASNA on the alleviation of the poverty of the clients of AKHUWAT.

\section{QUESTIONNAIRE:}

The questionnaire for collection of primary data from the beneficiaries of AKHUWAT is designed by adopting already tested questions by the following researchers.

1) REDA Kiflie Hayleeysus in his thesis on "Impact of Microfinance Institutions on poverty alleviation (A Case Study in Ethiopia) Sep2016, submitted in the Ritsumedkan, Asia Pacific University Ethiopia.

2) Ali Usman in his paper on "Analysis the impact of Microfinance on Poverty reduction" 2015 published in Journal of Poverty, Investment and Development.

3) Umara Naureen in her $\mathrm{PhD}$ thesis on "Impact of Microfinance on Poverty" 2010 submittedat Foundation University, Islamabad.

The designed questionnaire has been got approved from the AKHUWAT Head Office, Lahore and after incorporating the amendments suggested by the AKHUWAT, the questionnaire has been exercised by the researcher. 
The adopted questionnaire contains three parts.

Part-A: This part is regarding the demographic information of the beneficiaries like: Name, age, gender, religion, marital status, level of education, occupation, family size, No. of earning persons in the family, residential \& business addresses etc.

Part-B: This part is regarding the loan information like: No. of loans availed from AKHUWAT, purpose of the loan, utilization of the loan, other loans taken from other banks/institutions.

Part-C: $\quad$ This part is regarding the impact of the loan availed by the beneficiaries on their living standard and the satisfaction level of the beneficiaries regarding the loan availed and services of the Akhuwat.

\section{SAMPLE:}

A random sample of 120 beneficiaries i.e. approximately $10 \%$ of total active borrowers of AKHUWAT Hyderabad Branch were selected from the list provided by the Branch Officials. Out of 120 beneficiaries, 95 could be personally contacted by the researcher himself with the help/ support of the AKHUWAT Hyderabad Officials, however remaining 25 beneficiaries could not be contacted because of their non-availability at their residences due to certain reasons. Selected sample were 95 women and 25 men, whereas contacted sample were 70 women and 25 men.

\section{LOCATION OF THE BENEFICIARIES:}

As per AKHUWAT policy, the its Branch has to operate within 3 kilometers area around the branch premises, since AKHUWAT Hyderabad Branch is located at Latifabad Unit No. 9, therefore the jurisdiction of 
The Scholar Islamic Academic Research Journal

Vol. 5, No. 2 || July-December 2019 || P. 139-163

https://doi.org/10.29370/siarj/issue8ar14

Hyderabad Branch includes 8 units of Latifabad Area i.e. Unit Nos. 5, 6, 7 , $8,9,10,11 \& 12$. The majority of clients are located in Unit No. 5, $11 \&$ 12, therefore sample of the beneficiaries pertains to these units of Latifabad Area Hyderabad.

\section{COLLECTION OF PRIMARY DATA:}

The survey was conducted by the researcher himself with the help/support of the AKHUWAT Officials who were well known about the location of their clients. The researcher met personally with the beneficiaries of AKHUWAT Hyderabad Branch at their residences and interviewed them through designed questionnaire. Most of the beneficiaries are women and doing their businesses/work at their residences, amongst the 95 interviewed beneficiaries 25 are men and 70are women i.e. $79 \%$.

\section{ASSUMPTIONS AND LIMITATIONS OF THE STUDY:}

The contribution of this study should be viewed in light of some assumptions and limitations:

It is assumed that survey questions were answered by the respondents truthfully.

Familiarity of the respondents with the services and impact of microfinance were assumed.

Cooperation of the beneficiaries who participated in survey was relied upon.

The sample represents the population.

Information provided by the beneficiaries is based on their own experience and attitude.

Inadequate time in financial resources reduced the chances to contact more beneficiaries. 
The Scholar Islamic Academic Research Journal

Vol. 5, No. 2 || July-December 2019 || P. 139-163

https://doi.org/10.29370/siarj/issue8ar14

Accompany of Akhuwat official during survey may have changed the reply of respondents particularly regarding the questions of services provided by the Akhuwat.

Majority of the respondents was women therefore their reply regarding the age may not be correct.

Participation of the beneficiaries in the study was voluntary.

Population was limited to the clients of the Akhuwat Hyderabad branch.

There could be other impacts of microfinance that may have not been considered, tested and addressed exclusively.

\section{RESULTS AND DISCUSSIONS:}

The population size for the study is 1196 beneficiaries of Akhuwat Hyderabad Branch from which a sample of 120 beneficiaries were selected on randomly for conducting Interview through structured questionnaire.

The number of respondents who participated in the Interview survey is 95 beneficiaries i.e. $79.17 \%$, the same shown in following figure No.4-1.

\section{Figure 0-1 Number of Respondents during Survey}

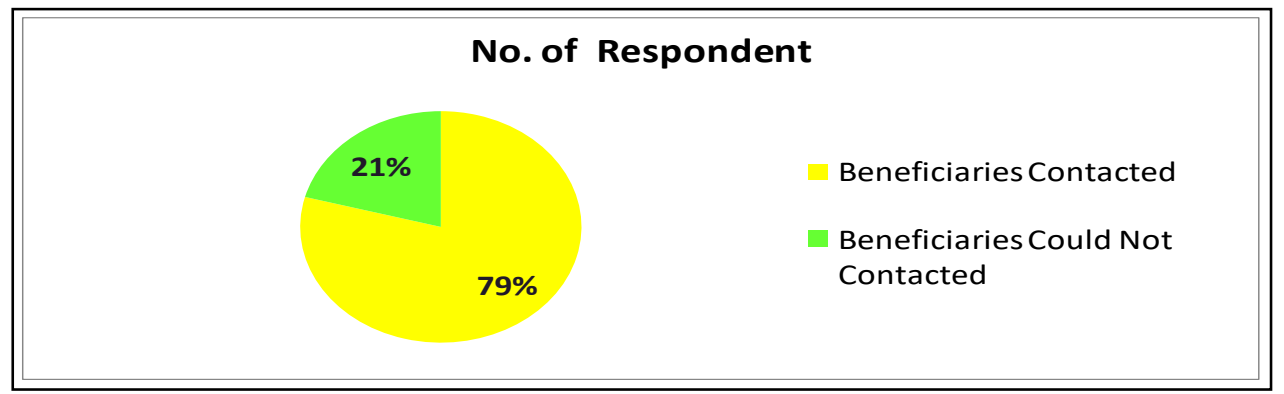

\section{DEMOGRAPHIC CHARACTERISTICS:}

The first part of the survey Questionnaire was on the information regarding the demographic characteristic of the beneficiaries. The 
The Scholar Islamic Academic Research Journal

Vol. 5, No. 2 || July-December 2019 || P. 139-163

https://doi.org/10.29370/siarj/issue8ar14

response of the beneficiaries has been summarized in the table No.4-1

given below:

Table 0-1 Demographic Characteristics

\begin{tabular}{|c|c|c|}
\hline Variable & Characteristics & Frequency \& \%age \\
\hline \multirow[t]{2}{*}{ Gender } & Male & $25, \quad 26.30 \%$ \\
\hline & Female & $70, \quad 73.70 \%$ \\
\hline \multirow[t]{2}{*}{ Religion } & Muslims & $91, \quad 95.80 \%$ \\
\hline & Non-Muslims & $04, \quad 04.21 \%$ \\
\hline \multirow[t]{5}{*}{ Age } & 11-20 Years & 02 , \\
\hline & & $2.10 \%$ \\
\hline & 21-30 Years & $31, \quad 32.63 \%$ \\
\hline & 31-40 Years & $44, \quad 46.32 \%$ \\
\hline & 40 and above & $18, \quad 18.95 \%$ \\
\hline \multirow[t]{5}{*}{ Education } & Nil & $36, \quad 37.89 \%$ \\
\hline & Primary / Middle & $28, \quad 29.47 \%$ \\
\hline & Metric & $23, \quad 24.21 \%$ \\
\hline & Intermediate & 6.32\% \\
\hline & Graduate & $02, \quad 2.11 \%$ \\
\hline \multirow[t]{4}{*}{ Marital Status } & Single & $08, \quad 8.42 \%$ \\
\hline & Married & $83, \quad 87.37 \%$ \\
\hline & Divorced & $01, \quad 1.05 \%$ \\
\hline & Widow & $03, \quad 3.16 \%$ \\
\hline \multirow[t]{4}{*}{ Family Size } & 01-04 Members & $27, \quad 28.42 \%$ \\
\hline & 05-08 Members & $\begin{array}{ll}56, & 58.95 \%\end{array}$ \\
\hline & 09-12 Members & $11, \quad 11.58 \%$ \\
\hline & 13-16 Members & $01, \quad 1.05 \%$ \\
\hline
\end{tabular}

The response given in above table No.4-1 envisages that: 
The Scholar Islamic Academic Research Journal

Vol. 5, No. 2 || July-December 2019 || P. 139-163

https://doi.org/10.29370/siarj/issue8ar14

More than $70 \%$ of the beneficiaries consist of the female. It envisages the empowerment of the women in provision of Qarz-e-Hasna for establishment / running of their business.

Most of the beneficiaries that is $67.00 \%$ are illiterate or having lower education. These have been given Qarz-e-Hasan to establish / run their business.

About $79 \%$ of the beneficiaries falls in the age group of 21 to 40 years. a young group of beneficiaries will definitely work hard for their business to improve their living standards.

$95 \%$ of beneficiaries are Muslims and $4 \%$ are Non-Muslims. It shows that Islamic Microfinance product has also been provided to Non-Muslims also.

$87 \%$ of the beneficiaries are married having their families. It envisages that Qarz-e-Hasna is supporting the poor families to enhance their level of living standards.

\section{QARZ-E-HASNA AVAILED AND ITS UTILIZATION:}

The part two of the survey questionnaire contains the information regarding the amount of loan availed by the beneficiaries and utilized it for the purpose. The information collected is reported in the table No.4-2 given below.

Table 0-2 Amount of Loan availed by the beneficiaries and utilized it.

\begin{tabular}{|l|l|l|}
\hline Variables & Characteristics & Frequency \\
& & \\
\hline
\end{tabular}


The Scholar Islamic Academic Research Journal

Vol. 5, No. 2 || July-December 2019 || P. 139-163

https://doi.org/10.29370/siarj/issue8ar14

\begin{tabular}{|l|l|c|}
\hline \multirow{3}{*}{$\begin{array}{l}\text { Qarz-e-Hasna } \\
\text { Availed }\end{array}$} & Rs. 15,000 & $07, \quad 7.37 \%$ \\
\cline { 2 - 3 } & Rs. 20,000 & $58, \quad 61.05 \%$ \\
\cline { 2 - 3 } & Rs. 25,000 & $20, \quad 21.05 \%$ \\
\cline { 2 - 3 } $\begin{array}{c}\text { Qarz-e-Hasna } \\
\text { Utilized }\end{array}$ & $\begin{array}{l}\text { Rs. } 30,000 \\
\text { (i) For the purpose } \\
\text { availed }\end{array}$ & $93,97.89 \%$ \\
\cline { 2 - 3 } & (ii) For another purpose & $02,2.11 \%$ \\
\hline
\end{tabular}

The above table No4-2 envisages that majority of beneficiaries i.e. $61 \%$ availed loan of Rs.20,000/- each whereas $21 \%$ availed loan of Rs.25,000/each, $11 \%$ availed loan of Rs.30,000/- each and $7 \%$ availed loan of Rs.15,000/- each.

The utilization of Qarz-e-Hasna availed by the beneficiaries is almost utilized for the purpose they availed for i.e. $98 \%$, however merely $2 \%$ did not utilized loan for the purpose they availed for.

recognition of beneficiaries regarding improvement in their living standard.

The first portion of the Part three of the survey questionnaire contains the information of the recognition of beneficiaries regarding the improvement in level of their living standard. The information collected is reported in the table No.4-3 given below:

Table 0-3 Recognition of beneficiaries regarding the improvement in level of their living standard

\begin{tabular}{|c|c|c|c|c|c|c|}
\hline $\begin{array}{c}\text { Sr. } \\
\text { No. }\end{array}$ & Description & $\begin{array}{c}\text { Greatly } \\
\text { Improved }\end{array}$ & $\begin{array}{c}\text { Somewhat } \\
\text { Improved }\end{array}$ & $\begin{array}{c}\text { Remain } \\
\text { Same }\end{array}$ & $\begin{array}{c}\text { Somewhat } \\
\text { Worsen }\end{array}$ & $\begin{array}{c}\text { Greatly } \\
\text { Worsen }\end{array}$ \\
\hline 1 & Income Level & 14 & 62 & 19 & - & - \\
\hline
\end{tabular}


The Scholar Islamic Academic Research Journal

Vol. 5, No. 2 || July-December 2019 || P. 139-163

https://doi.org/10.29370/siarj/issue8ar14

\begin{tabular}{|c|c|c|c|c|c|c|}
\hline 2 & $\begin{array}{l}\text { Expenditure } \\
\text { Level }\end{array}$ & 1 & 56 & 37 & 1 & - \\
\hline 3 & Saving Level & - & 70 & 24 & 1 & - \\
\hline 4 & Education Level & - & 51 & 42 & 2 & - \\
\hline 5 & $\begin{array}{l}\text { Health } \\
\text { Conditions }\end{array}$ & - & 43 & 50 & 2 & - \\
\hline 6 & $\begin{array}{l}\text { Household } \\
\text { Assets }\end{array}$ & 4 & 45 & 45 & 1 & - \\
\hline 7 & Business Assets & 9 & 72 & 14 & - & - \\
\hline 8 & $\begin{array}{l}\text { Position in } \\
\text { Society }\end{array}$ & - & 39 & 56 & - & - \\
\hline 9 & $\begin{array}{l}\text { Position in } \\
\text { Business } \\
\text { Community }\end{array}$ & - & 38 & 57 & - & - \\
\hline & TOTAL & 28 & 476 & 344 & 7 & $\mathbf{0}$ \\
\hline & Percentage & $3 \%$ & $56 \%$ & $40 \%$ & $1 \%$ & $0 \%$ \\
\hline
\end{tabular}

The data given in the above table No.4-3 is produced through Pie chart in order to understand the response of the beneficiaries regarding their recognition on improvement in their living standard because of the Microfinance facility provided to them by the Akhuwat. 
The Scholar Islamic Academic Research Journal

Vol. 5, No. 2 || July-December 2019 || P. 139-163

https://doi.org/10.29370/siarj/issue8ar14

Figure 0-1 Improvement in living standard of the beneficiaries of Akhuwat product of "Qarz-e-Hasna" recognized by them.

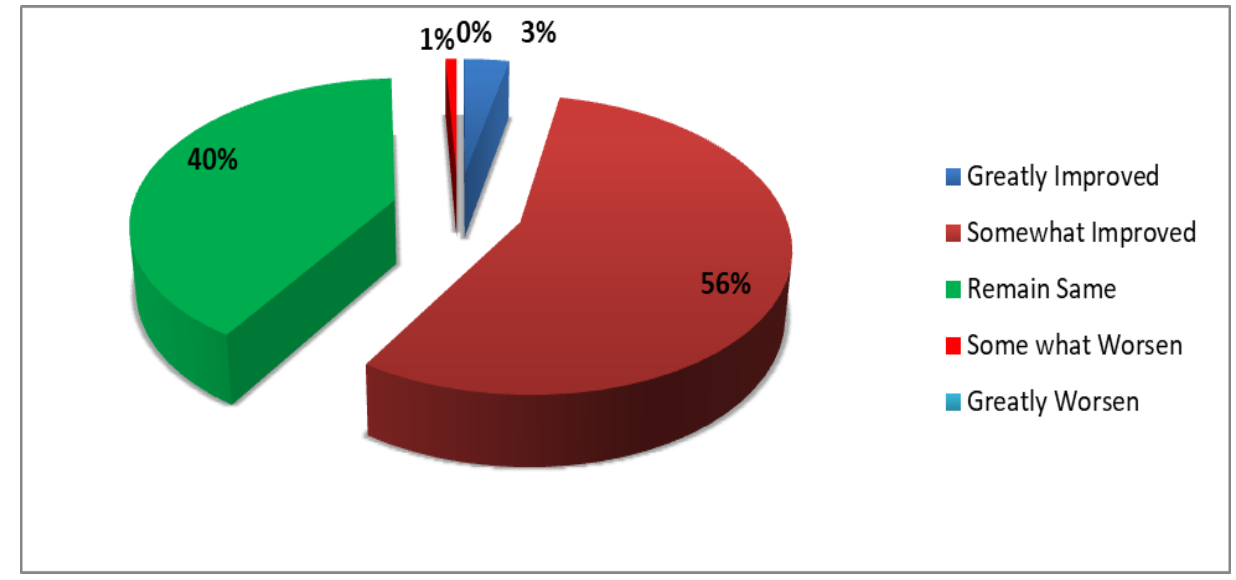

The above figureNo.4-2 depicts that 3\% of beneficiaries of Qarz-e-Hasna of the Akhuwat have improved their living standard greatly, about 56\% beneficiaries have recognized that their living standard somewhat improved, however, living standard of $40 \%$ beneficiaries remain same and of $1 \%$ somewhat worsen.

\section{SATISFACTION LEVEL OF THE BENEFICIARIES REGARDING THE SERVICES OF}

AKHUWAT:

The second portion of the Part three of the survey questionnaire contains the information of satisfaction level of beneficiaries regarding the services of Akhuwat. The information collected is reported in the table given below:

Table 0-4 Satisfaction level of beneficiaries regarding the services of Akhuwat. 
The Scholar Islamic Academic Research Journal

Vol. 5, No. 2 || July-December 2019 || P. 139-163

https://doi.org/10.29370/siarj/issue8ar14

\begin{tabular}{|c|c|c|c|c|c|}
\hline Description & $\begin{array}{c}\text { Very } \\
\text { Satisfied }\end{array}$ & Satisfied & Neutral & Dissatisfied & $\begin{array}{c}\text { Very } \\
\text { dissatisfied }\end{array}$ \\
\hline Amount of Loan & 3 & 79 & 11 & 2 & - \\
\hline Charges of Loan & 3 & 75 & 16 & 1 & - \\
\hline $\begin{array}{l}\text { Loan Processing } \\
\text { Time }\end{array}$ & 3 & 82 & 8 & 2 & - \\
\hline $\begin{array}{l}\text { Re-payment } \\
\text { schedule }\end{array}$ & 3 & 91 & 1 & - & - \\
\hline Overall Services & 53 & 41 & 1 & 1 & - \\
\hline TOTAL & 65 & 368 & 37 & 6 & $\mathbf{0}$ \\
\hline Percentage & $14 \%$ & $77 \%$ & $8 \%$ & $1 \%$ & $0 \%$ \\
\hline
\end{tabular}

The data given in the above table No.4-4 is produced through Pie chart in order to understand the response of the beneficiaries of their satisfaction level regarding the services of Akhuwat.

Figure 0-2 Satisfaction level of beneficiaries regarding the services of Akhuwat.

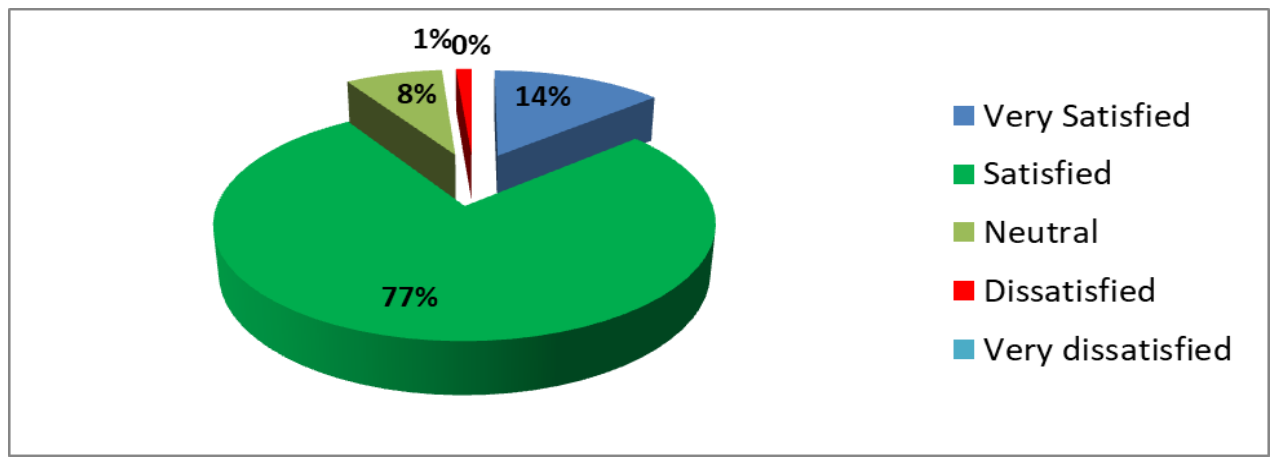

The above figure No.4-3 depicts that $14 \%$ of beneficiaries of Qarz-eHasna of the Akhuwat are very satisfied with the services of Akhuwat, 
The Scholar Islamic Academic Research Journal

Vol. 5, No. 2 || July-December 2019 || P. 139-163

https://doi.org/10.29370/siarj/issue8ar14

about $77 \%$ beneficiaries are satisfied, however, satisfaction level of $8 \%$ beneficiaries remain neutral and of $1 \%$ dissatisfied.

\section{FINDINGS ANDCONCLUSIONS :}

On the basis of analysis of primary data, the findings and conclusion of the study are discussed below:

It is found that majority of the beneficiaries were Muslim women within the age groups of 21 to 40 years have obtained the loan of Rs. 20,000/each and utilized it for the purpose to expand and run their small businesses, merely $2 \%$ of the beneficiaries could not utilized the loan for the purpose. Since $1^{\text {st }}$ objective of this study was "To critically view the utilization of QARZ-E-HASNA availed by the poor for the productive and social purpose" therefore from this finding it is concluded that the loan availed by the beneficiaries has been utilized for the purpose they obtained for.

The results of analysis indicates that the Islamic Microfinance product Qarz-e-Hasna has significant impact on the living standard of the beneficiaries on account of improvement in their income, expenditure, saving, educational level, household assets and business assets, majority of the beneficiaries are satisfied with the terms of loan and the services of Akhuwat. On the contrary majority of the beneficiaries responded that their position in the society and business community remain same after obtaining credit from the Akhuwat. Since $2^{\text {nd }}$ objective of this study was "To analyze the impact of QARZ-E-HASNA on the alleviation of the 
poverty of the clients of AKHUWAT'from this finding it is established that the impact of Qarz-e-Hasna on the alleviation of the poverty of the beneficiaries of Akhuwat is positive.

\section{RECOMMENDATIONS:}

This study is limited to the area of Hyderabad city therefore, may not be generalized, however it is recommended that this type of study may be conducted at wider area at least provincial level for appropriate findings.

The limit of Qarz-e-Hasna amount may be increased at minimum Rs.100,000/- per beneficiary so that it can be utilized by the beneficiaries in these days of hyperinflation.

To further stable financial position of the Akhuwat efforts may be focused on more donations from the philanthropist organizations and individuals of the country as well as some kind of operational charges may be charged from the beneficiaries to increase the income of the Akhuwat as charging of operational costs are allowed in the religion of Islam.

At present Akhuwat is providing credit facilities to its beneficiaries, however, other Microfinance facilities like Saving Accounts, Insurance / Takafull Services and Funds Transfer Services may also be provided to enhance the scope of Akhuwat.

During the survey it was observed that Akhuwat Hyderabad Branch was not extending loan facilities for the new entrance who wants to start their businesses as well as there were no facility of social loans for the poor. It is therefore recommended that Akhuwat Hyderabad Branch may also 
The Scholar Islamic Academic Research Journal

Vol. 5, No. 2 || July-December 2019 || P. 139-163

https://doi.org/10.29370/siarj/issue8ar14

entertain new entrance for the facility as well as also introduce social loans

for the poor who wants to avail this facility for their social purposes like marriages, education and repayment of interest based loans.

It is recommended that like other government agencies of Pakistan Sindh government alsoinitiate the efforts to provide interest free loan for the poor and unemployed youths through Akhuwat so that can contribute in eradication of poverty and unemployment from the provinc.

\section{(ब)(๑)}

Attribution-NonCommercial-ShareAlike 4.0 International (CC BY-NC-SA 4.0) 